\title{
THE GOOD GRAY POET AND THE QUAKER OATS MAN: SPEAKER AS SPOKESCHARACTER IN LEAVES OF GRASS
}

\author{
BRADY EARNHART
}

When one of OsCar Wilde's BRILLIANT DANDiEs aphorizes that “Good artists exist simply in what they make, and consequently are perfectly uninteresting in what they are," he offers a reactionary response to a common real-life problem; the gist of his message might have saved Anne Gilchrist, for one, a lot of heartache. ${ }^{1}$ As anyone familiar with Walt Whitman's life will recall, he and Gilchrist had never met when he received the first of a torrent of letters from her in 1871 . He must have been astonished as what amounted to a marriage proposal unfolded before his eyes: Gilchrist expressed a hope that he would come to call her "Bride, wife, indissoluble eternal!" Finding her hard to deter (she would eventually move to Philadelphia to be near him), he gently warned her not to "construct such an unauthorized \& imaginary ideal Figure, \& call it W.W. and so devotedly invest [her] loving nature in it."

This is, of course, a disingenuous response, as David S. Reynolds has pointed out (492). After all, what is "Walt Whitman, an American, one of the roughs, a kosmos" if not the poet's imaginary idealization of himself? ${ }^{3}$ Effacing the distance between poet and text is a primary motif in Leaves of Grass; Gilchrist acknowledged this when she praised a now-famous passage generally overlooked by nineteenth-century commentators:

Walt Whitman's poems are not the biography of a man, but they are his actual presence. It is no vain boast when he exclaims,

"Camerado! this is no book;

Who touches this touches a man."

He has infused himself into words in a way that had not before seemed possible; and he causes each reader to feel that he himself or herself has an actual relationship to him, is a reality full of inexhaustible significance and interest to the poet. ${ }^{4}$

The speaker in Whitman's poems locates himself within the physical book- "Listener up there!," "Whoever you are holding me now in 
hand"-in order to sing "independently" of the poet (CPCP 87, 270). More recent critics have returned again and again to this feature of Whitman's work. M. Jimmie Killingsworth calls it by Paul de Man's term "prosopopoeia." 5 John Irwin describes it as making "the poetic self the sole referent of the poem," a trope by which Whitman "circumvents the absence of the live speaking voice." Terry Mulcaire and Andrew Lawson both explore the continuity between Whitman's inspiriting of the mass-produced object and his contemporary Karl Marx's belief that capitalism reduces workers to the status of commodities. ${ }^{7}$ Whitman's "publishing intimacy" is particularly interesting to Mulcaire, who finds in it a reversal of the terms of Marx's tragic equation. To paraphrase Frederick Douglass: at a time when men were being made into commodities, Whitman set for himself the task of turning a machine-made commodity into a man. By investing Leaves of Grass with a human identity, he offered the act of reading the mass-produced book as a corrective to the social disintegration that mass production itself had helped bring about.

Gilchrist was neither the first nor the last reader to swoon over a favorite author, but few texts invite so explicitly as Leaves does a conflation of the book and the book's creator. The fact I would like to draw attention to here is that this text appeared in the midst of a similar phenomenon in early modern advertising. At roughly the same time that Gilchrist's letter was steaming its way toward Camden, consumers across America were experiencing what we might describe as an epidemic of Gilchristian confusion. A quick example: in the mid-1870s, Aaron Montgomery Ward decided to decorate his fledgling company's catalogues with pictures of the company's founders and facsimiles of their signatures. His goal was to encourage distant customers to take the then-radical step of purchasing goods over the mail, but the familiarization strategy succeeded in ways he never anticipated. Though no customers that I know of actually proposed marriage to him, many went so far as to write that they had given their babies his name, and several hundred felt confident enough to enlist him as a matchmaker. One wrote,

Please send me a good wife. She must be a good housekeeper and able to do all household duty. She must be 5 feet 6 inches in height. Weight $150 \mathrm{lbs}$. Black hair and brown eyes, either fair or dark.

I am 45 years old, six feet, am considered a good-looking man. I have black hair and blue eyes. I own quite a lot of stock and land. I am tired of living a bachelor life and wish to lead a better life and more favorable.

Please write and let me know what you can do for me. ${ }^{8}$

The ultra-personal producer/customer relationship such letters bespeak is accidental only in degree. Ward put the photos in the catalogue with every intention of appealing to the consumer's nostalgia for a more direct, pre-industrial contact with the source of the product - a contact 
that the consumer presumably felt had been diminished through the mediation of mass production. Constructing imaginary, idealized figures of manufacturers in order to create an illusion of immediate contact has, in fact, been a primary occupation of advertisers over the century and a half that their profession, as such, has existed. Whitman's attempt "to sexualize the physicality, indeed the erotic nature of the book itself"-as Mulcaire phrases it - partakes of a deeply similar strategy. ${ }^{9}$ Whitman wrote, "Stop this day and night with me," "Spread your palms and lift the flaps of your pockets," "Push close my lovers and take the best I possess" (CPCP 28, 72, 89); the television today still echoes, "Why ask why?" "Just do it," "Reach out and touch someone." It is worth the effort of defamiliarization it takes for us to realize that communing with "Walt Whitman," drinking milk from Elsie the cow, and eating bologna that has a first and a last name are acts that spring partly from a common set of cultural circumstances. In this article, I would like to sketch these circumstances and how they might inform our understanding of the long foreground of Whitman's mature writing. Though he had deeply mixed feelings about advertising, and though its thematic presence within Leaves of Grass has only in recent years gained serious critical attention, ${ }^{10}$ the record suggests that his immersion in the rapidly growing advertising industry was a key factor in his learning the importance and some of the methods of making a mass-produced commodity feel like a close friend.

Modern commercial animism is a relatively new spin on a very old kind of marketing magic. In ancient Rome, a painting of a mill being turned by a donkey designated a bakery; a boy being whipped was the sign for a school. English inns from the Middle Ages onward took their names and insignias from coats of arms or to connote abstract qualities: the lion for courage, the bull for strong drink. By the early eighteenth century, a writer in The Spectator called London's commercial streets a menagerie of "Blue Boars, black Swans, and red Lions, not to mention flying Pigs, and Hogs in Armour, with many other Creatures more extraordinary than any in the Desarts of Africk."11 This colorful symbolism had value beyond the merely descriptive. Widespread illiteracy meant that a familiar red and white pole, for instance (a holdover from the days when barbers also served as blood-letters), would get more customers than a sign that said "Barber" would.

Given the high literacy rate of nineteenth-century America, however, animistic advertising caught on here for a different reason: its appeal to the nostalgia of a rapidly urbanizing population. Jackson Lears has identified the use of advertising characters with an effort "to overcome the sense of separation and loss endemic in a mobile market society, to recreate in fantasy what could not be achieved in everyday life-a renewed connection with the Gemeinschaftliche worlds of extended family, 
local neighborhood, and organic community." 12 Though this strategy took decades to coalesce, its antebellum manifestations include the domesticated pastoral scenes of Currier \& Ives prints, the idealization of rural innocence in literature and song, and, increasingly, in trade cards and ads for products like Wright's Indian Vegetable Pills or Paine's Celebrated Green Mountain Balm of Gilead and Cedar Plaster. In order to "establish some common ground, some sense of old-shoe familiarity between the purchaser and the product," ads taught consumers to associate factory-produced goods with fanciful human or quasi-human identities. ${ }^{13}$

Over the mid- to late nineteenth century, manufacturers across the country (increasingly helped by professional ad writers) worked to disguise the impersonal, modern marketplace as a giant home, and their characterizations became spectacularly successful branding tools. Often - as in the cases of Aunt Jemima, the Jolly Green Giant, or Mr. Clean-advertising characters have performed as stand-ins for the manufacturer, on the understanding that "customers would find it more comfortable to deal with a seller whose personal image was familiar-and perhaps carried an aura of dignity, integrity, or friendliness - than with an anonymous corporation." 14 The Quaker Oats man made his debut in 1878 on boxes of the first mass-marketed breakfast food; to lend his cereal a paternal, homespun integrity, Henry Crowell had labeled them with a picture of a Quaker he had found in an encyclopedia. Whitman's own grandfatherly face appeared on boxes of cigars, even though the poet never smoked (Reynolds 210,569). ${ }^{15}$

Sales of Lydia Pinkham's “female complaints" remedy, "Pinkham's Vegetable Compound," took off in 1879 when she took her son Daniel's suggestion and started putting her picture on bottles and ads. She soon had what ad historian Stephen Fox calls "the most universally recognized female face of the day." 16 Another late 1870s entrepreneur, shoemaker William L. Douglas, decided to decorate his ads with his own likeness after admiring a poster of P.T. Barnum. Douglas's "bald pate, droopy mustache, and earnestly fretful look" became so famous that correspondents learned they could reach him simply by pasting his picture on an unaddressed envelope. ${ }^{17}$ The makers of Mennen's Toilet Powder even used "Mennen's face on every box" as their slogan. As Roland Marchand relates, an image of the producer "seemed to guarantee that a real person, with his identity publicized and his reputation thus placed on the line, stood behind the product." 18 By the early twentieth century, advertisers with all kinds of clients had populated American media with a huge cast of similar advertising characters - some more heavily fictionalized than others. They were lovingly described in one advertising trade journal as "the smiling chef of Cream-of-Wheat, the frolicky Gold-Dust Twins, the gaily youthful, toothful Sozodont girl, the round-eyed chubs who fatten to bursting on Campbell's Soups, and the hale old friend of Quaker Oats." 19 
Naming the clock Big Bill endows it with personality, makes it a sentient being, takes it out of the class of alarm clock-it is not an alarm clock, it is Big Bill. And people will actually pay the big new price because you tell them that he, not "it," is a big, fine, jolly fellow with a brave, cheerful voice. ${ }^{20}$

Whitman's use of a self-portrait in place of a conventional frontispiece in 1855 is only the most obvious parallel to the animistic strategy of his advertising contemporaries. ${ }^{21}$ His transformation into a mass-producible image is facilitated by multiple idealizations, both verbal and visual, of his own body. This is a rarely recognized side-effect of his using the third-person pronoun in his self-reviews of the 1855 Leaves of Grass:

Of pure American breed, of reckless health, his body perfect . . . ample limbed, weight one hundred and eighty-five pounds, age thirty-six years (1855) — never dressed in black, always dressed freely and clean in strong clothes, neck open, shirt-collar flat and broad, countenance of swarthy, transparent red, beard short and well mottled with white, hair like hay after it has been mowed in the field and lies tossed and streaked-22

The description is strikingly two-dimensional; it has as much to do with appearance, and as little with the quality of its subject, as the kindly face on the Quaker Oats box. For the review to assert some highbrow notion of literary merit would be, of course, beside the point. Whitman is presenting his work as a human entity in itself. His appeal to pre-industrial nostalgia is enhanced by the pastoral imagery he chose for the cover of the edition. Reynolds describes the cover as evidence of Whitman's "interest in dissolving boundaries between different cultural levels," but it might be more accurate to say he was hedging his bets. Following the example of Fern Leaves from Fanny's Portfolio (1853), Whitman's leafy embossment trades on a bucolic ideal belied by its own sophisticated production values.

Like many manufacturers of his day, Whitman was the first advertiser of his own product. As many other manufacturers also did, he experimented with naming the product and its residing genius after himself, even as he sublimated his identity as their physical creator. Within the 1855 poem later entitled "Walt Whitman" and eventually "Song of Myself," the speaker famously identifies himself as "Walt Whitman" and "Walt" while the author of the book restricts his own use of the name (in its less personal form "Walter Whitman") to a small-print copyright notice $(C P C P 50,53)$. In the place of a conventional by-line in this edition, Whitman substituted his decidedly unbusinesslike, devil-may-care engraving. Though anomalous in its time, this act presaged the invention of later fictional figureheads such as the invisible but venerable "Gray Lady" of The NewYork Times and her nephew The NewYorker's monocled "Eustace Tilley." Regardless of the part vanity might have played in 
Whitman's layout, the reader's interest in the figure portrayed on the frontispiece does not in the slightest rely upon its resemblance to the fleshand-blood author. Instead, this portrait functions mainly to imbue the publication with its own personality. Though the philosophical density and passion of Whitman's work tend to distract us from its resemblance to advertising, his speaker and common advertising spokescharacters similarly offer visible, immediate personifications of producers whom consumers might deem too distant or boring to identify with.

In his 1866 pamphlet entitled The Good Gray Poet: A Vindication, Whitman's champion William Douglas O'Connor (himself a sometime editor) contributed to the Leaves of Grass ad campaign by giving the speaker an unforgettable nickname and sanitizing Whitman's image for the middle classes. Like Whitman, O'Connor goes to great lengths to give his audience a visual conception of his subject, as though looks provided the greatest proof of quality:

a man of striking masculine beauty - a poet - powerful and venerable in appearance; large, calm, superbly formed; oftenest clad in the careless, rough, and always picturesque costume of the common people; resembling, and generally taken by strangers for, some great mechanic, or stevedore, or seaman, or grand laborer of one kind or another ... the whole form surrounded with manliness, as with a nimbus, and breathing, in its perfect health and vigor, the August charm of the strong. ${ }^{23}$

This is a passage Whitman could easily have written himself. ${ }^{24}$ It continues the emphasis on height, beauty, morality, strength, and health found in the self-reviews-qualities so irrelevant to the production of fine poetry that there is little choice but to see them as commercial lures. The title of the pamphlet is particularly interesting in conjunction with O'Connor's claims for his subject's good health: "Good Gray Poet" employs the catchy alliteration common among patent medicine brand names like "Sand's Sarsaparilla," "Carter's Little Liver Pills," and "Brown's Iron Bitters."

What brought Whitman into the unlikely company of captains of industry? First, he was an insider, with an attitude toward mass production that was, for the most part, as sanguine as we might expect an insider's to be. Printing, which had been the first mass-production technology of any kind, was revolutionized in Whitman's formative years by the replacement of the flat-bed with the cylinder press. As a typesetter for Park Benjamin's New World in 1842, Whitman was a member of the first generation ever to work with cylinder presses; he was also among their earliest direct beneficiaries, publishing his popular temperance novel Franklin Evans as an extra to the New World in the same year. ${ }^{25}$ He described the mid-century publishing boom as "nourishment" for literary "giants" in America. "Of the twenty-four modern mammoth two-double, three-double, and four-double cylinder presses now in the 
world, printing by steam, twenty-one of them are in These States," he pointed out proudly in his 1856 open letter to Emerson. His enthusiasm could be surprisingly undiscriminating:

[T] he three thousand different newspapers, the nutriment of the imperfect ones coming in just as usefully as any-the story papers, various, full of strong-flavored romances, widely circulated - the one-cent and two-cent journals - the political ones, no matter what side - the weeklies in the country - the sporting and pictorial papers - the monthly magazines, with plentiful imported feed-the sentimental novels, numberless copies of them - the low-priced flaring tales, adventures, biographies - all are prophetic; all waft rapidly on. (CPCP 1329)

Whitman tended to identify closely with the machinery of book manufacture. Metaphors of print surface frequently in his discussions of writing. In the margin of an 1848 newspaper article on Keats he wrote, "The great poet absorbs the identity of others ... but he $\mathrm{p}$ [erceives] them all through the powerful press of himself." ${ }^{26} \mathrm{He}$ borrowed the industrial language of his own self-review to exhort an imaginary student, "Rest not till you rivet and publish yourself of your own Personality" (CPCP 515). In a poem of the same period he described himself "imprinting my brain for future use with ... shows, architecture, customs, and traditions" ("Once I Pass'd Through a Populous City," 266). In his open letter to Emerson, the notion of self as machine took the form of a boast: "the work of my life is making poems. I keep on till I make a hundred, and then several hundred-perhaps a thousand." Reynolds has aptly described this passage as a scene of "mass production, as though he saw himself as a poetry factory forever stepping up output in order to satisfy broadening demand" (356).

Nonetheless, Whitman was also familiar with the destabilizing effects industrialization could have. Between his birth and the Civil War, the population of Manhattan roughly quintupled, while Brooklyn's skyrocketed from around 5,000 to over 200,000 (Reynolds 30). Factories were edging women out of home textile production. Vertical institutions-fatherhood, local government, church-lost power over boys who moved into horizontal social systems at lower and lower ages. ${ }^{27}$ Traditional community ties weakened as families moved or split up to find work. "To say nothing of breaking things (mirrors, crockery, fragile legs, and the like)," Whitman wrote in 1858, "very large quantities of the human peace, good feeling, and matrimonial temper, are surely put in limbo, and, perhaps maimed for life, by moving." ${ }^{28} \mathrm{He}$ had plenty of first-hand experience to draw from. Between his birth and the Civil War, he lived at fourteen different addresses in Brooklyn alone, plus several more in New Orleans and Manhattan; it is poetically apropos that what appears to have been his longest romantic relationship began on the road-in a Washington horse-car with Irish-born conductor Peter Doyle (Reyn- 
olds 24, 84, 487). Apprenticed first to his carpenter father and more formally to printers from an early age, Whitman was also a champion of the skilled craftsman at a time when the workplace was growing progressively mechanized and anonymous. His advocacy of a system in which "the author might be the maker even of the body of his book- set the type, print the book on a press, put a cover on it, all with his own hands" seemed quaint at a time when specialization was gradually alienating authors from the production process (Reynolds 46-47).

From time to time, the habitual boosterism of Whitman's cityscapes was checked by doubts about the effects of industrialization on human beings. His misgivings about the "deadening" influence of industrial rhythms had surfaced in "Philosophy of Ferries," an 1847 Eagle article that Betsy Erkkila has rightly described as "Chaplinesque." Crowds are herded on board as if by "iron-willed destiny" and homogenized by the discipline of the bell: "Now see them as the said three-tap is heard! Apparently moved by an electric impulse, two-thirds of the whole number start off on the wings of the wind! Coat tails fly high and wide! You get a swift view of the phantom-like semblance of humanity, as it is sometimes seen in dreams - but nothing more." 29 In the 1855 Leaves of Grass he echoed, "Men and women crowding fast in the streets .. If they are not flashes and specks what are they?" recalling the spirit of Poe's edgy short story "A Man in the Crowd" and anticipating the atomistic urban scenes of impressionist painters (CPCP 139).

\section{Personal fournalism}

Whitman saw the press as one of the most promising avenues for unifying an increasingly fragmented American society, but there were obstacles. Many potential readers lacked the education or money to follow the reputable papers of the day, while others simply felt the tone of the papers held them at arms' length. As late as 1858, Whitman would alternately despair of the "large and numerous class, aye, the most numerous, especially in the great cities, who are . . beyond, or rather below, the influence of the papers they do not or cannot read," on one hand, and of "the public who regard the terrible 'We' as a semiomniscient and omnipotent being" on the other (I Sit 35-36, 34). The most blatantly market-driven responses to this alienation were "sensation stories" of vice, murder, and heartbreak. Whitman, who had dabbled in sensationalistic writing himself, affected to look on these with patronizing good humor, defending them from harsher critics on the grounds that "the public for whom these tales are written require strong contrasts, broad effects and the fiercest kind of 'intense' writing generally." ${ }^{30}$ But closer to his heart was a solution that came to be known as "personal journalism," a trend that had its first burst of popularity from the rise 
of the penny press in the 1830s until the Civil War brought a sudden demand for hard news. ${ }^{31}$ The ancestors of today's human-interest and society columnists, personal journalists typically adopted the subjective, morally didactic conventions of romantic historians. As William E. Huntzicker says, "Like romantic heroes, [they] derived their power from relationships with people. Their narratives and characters provided them the means to tell stories that resonated with American readers." ${ }^{32}$ Comfortingly ordinary in diction, sometimes gossipy in subject matter, these stories employed a producer-to-consumer intimacy essentially like that which advertising professionals began using on a large scale in the last decades of the nineteenth century. ${ }^{33}$ Some editors drew ridicule for blurring the lines between the news and their personal lives in the process. ${ }^{34}$ A wild stagecoach ride taken by The New York Daily Tribune's Horace Greeley was so widely publicized that Mark Twain claimed to have seen it printed in nine different languages; "I have heard it is in the Talmud," he quipped. ${ }^{35}$ James Gordon Bennett, the self-styled "genius of the newspaper press" who founded and edited the New York Herald, did not shrink from comparing himself to Shakespeare, Napoleon, or Moses; others would more often compare him to P.T. Barnum. Though he was widely reviled for giving prominent coverage to his own personal life (a first-person story on his 1840 engagement made the Herald's front page), doing so helped Bennett practice his populist philosophy: he wrote that "An editor must always be with the people-think with them-feel with them." 36

My point here is that, in various ways, penny-press-era editors constructed identities for themselves within their papers to the end of inviting a broader readership. Along with the probably considerable element of civic-mindedness involved, a clear financial motive spurred them to methods that anticipated later advertising character creation. The important formal difference lies in the fact that their identities were not visual images blazoned on labels or ads but were, in essence, ads within the product itself. Whitman excelled at personal journalism as a writer and editor in the 1840s, as Ezra Greenspan has discussed at some length. ${ }^{37}$ An 1846 editorial shows the poet following Bennett's example by emphasizing the importance of an emotional connection between the Eagle and its readers: "There is a curious kind of sympathy (haven't you ever thought of it before?) that arises in the mind of a newspaper conductor with the public he serves. He gets to love them. Daily communion creates a sort of brotherhood and sisterhood between the two parties" (UPP I, 115). ${ }^{38}$ The strategy may have worked: one of the letters to the editor that Whitman chose (or, who knows - ghostwrote?) for the September 23, 1846, edition even addressed him as "Mr. Brooklyn Eagle." Whitman played with his identity in a similar way when he signed the name "Paumanok" to a series of journalistic letters to the New York 
Evening Post, and when, in a Brooklyn Daily Times article, he referred to himself as "Mr. Items" (UPP I, 250; I Sit 148). In an 1851 freelance article on music, his identification with the paper in the reader's hand becomes very nearly that which his speaker was soon to claim in Leaves of Grass: "Come, I will not talk to you as to one of the superficial crowd who saunter here because it is a fashion; who take opera glasses with them, and make you sick with shallow words, upon the sublimest and most spiritual of the arts. I will trust you with confidence; I will divulge secrets" (UPP I, 256)..$^{39}$

Editor Samuel Bowles would lament in 1872 that "With the deaths of James Gordon Bennett and Horace Greeley, Personal Journalism also comes practically to an end. .. . Their personality was the necessity of their creative work, and it could not be suppressed by inks and types." ${ }^{40}$ It is hard to ignore the (no doubt unconscious) parallel between this last sentence and Whitman's 1855 plaint: "I was chilled with the cold types and cylinder and wet paper between us. / I pass so poorly with paper and types .... I must pass with the contact of bodies and souls" (CPCP 89). Reaching out through the paper to grasp the reader was one of the defining gestures of penny-press era newspaper editors, and it was of vital importance to the development of Whitman's internal self-promotion.

\section{Competition}

The gentle, arm-around-the-shoulder tone of personal journalists and advertising characters alike has disguised the jealously exclusive nature of the relationship they desired; without the threat of lethal competition from each other, manufacturers would very likely never have thought to address the reader so warmly. A little background is in order here. Up until around the late 1840s, since wholesalers had bought from whomever could provide a reasonably trustworthy product at the lowest price, few companies had had recognizable names at all. Large-scale manufacturers were relatively few and relatively anonymous, and most advertising per se remained humble and product-oriented. Newspaper ads were likely to read simply "Paint and Oil Store," "Large and Good Bread," or "Oats," followed by a supplier's name (almost always in smaller type) or an address. The absence of brand names in one of Whitman's own 1846 Eagle articles is instructive:

About that part of South street, near the Battery, is the great rendezvous for the flour trade, the canal boats, grain, and so on. You will observe divers sloops and schooners, or a dirty green, with such information as this chalked on an old slab of board and hung up conspicuously: 


\section{"Jersey Corn, \\ Canal Oats, and \\ Ship Stuff." 41}

Over the next fifty years, the advertising landscape changed vastly. With the rise of industrial manufacture, supply began to outstrip demand, creating a spirit of competition that Whitman celebrated in the preface to the 1855 Leaves: "The American bards shall be marked for generosity and affection and for encouraging competitors" (CPCP 15). Much more often than they invented new products, Americans went into business modernizing the production of items whose popularity was already proven. It was competition among such manufacturers that led to branding - the act of identifying and distinguishing various products in consumers' eyes. Only by developing a good reputation could one generate enough demand to get retailers to stock a particular brand. ${ }^{42}$ Advertising became essential to manufacturers not exactly because it "created a desire," but because it counteracted what Lears calls "the tendency for the reader's eyes to glaze over when confronting a mass of competing appeals for increasingly standardized products"; the most pressing concern was not, in other words, the lack of demand for wagons or chocolate but the lack of demand for Studebaker wagons and Baker's chocolate. ${ }^{43}$ Since consumers would ask for a product they knew by name, even if it was a little more expensive than others, branding freed manufacturers to set prices for the first time. Creating a feeling of acquaintanceship by humanizing a company's identity - often with the aid of a catchy spokescharacter - thus became doubly important, and advertising became a viable profession. ${ }^{44}$

The enormously competitive mid-nineteenth century newspaper industry in which Whitman grew up was a bellwether of this trend. When he bought a press and types as a teenager and started his own weekly newspaper, advances in paper-making and printing technology were bringing a tremendous boom to the industry - and with it, the "fierce spirit of competition and rivalry" that became the most distinctive feature of the penny press. ${ }^{45}$ Lower production costs and rising ad revenues enabled papers to begin weaning themselves of political party support for the first time. Between 1839 and 1845, at least forty new independent papers were launched in New York. Bennett and other editors conducted a "newspaper war," accusing each other on slim evidence of plagiarism, bias, and general "dastardliness" and, incidentally, increasing their circulation through the scandal. ${ }^{46}$

Among the newspaper warriors, Whitman singled out editor Robert Bonner for special praise as "the hero of unheard-of and tremendous advertising, who fires cannon, fills page upon page of newspapers, and - if he could - would placard the very walls of Paradise with hifalutin 
handbills, to sell that gorgeous and unprecedented sheet, the New York Ledger" (qtd. in Reynolds, 344). In the same year that Leaves of Grass was published, Bonner was astonishing his readers by paying writer Fanny Fern the unheard-of rate of one hundred dollars a column, a fact that made news in its own right. Three years later he would spend up to twenty-seven thousand dollars a week to advertise his Ledger. Within a decade, the chances he took made him a millionaire. ${ }^{47}$ It is easy to see how Whitman, whose independent publication of Leaves had required him to take considerable chances of his own, would admire such entrepreneurial skill. He could have had either Bonner or himself in mind when he wrote,

\footnotetext{
What is commonest and cheapest and nearest and easiest is Me, Me going in for my chances, spending for vast returns,

Adorning myself to bestow myself on the first that will take me, Not asking the sky to come down to my goodwill,

Scattering it freely forever. (CPCP 38)
}

The passage implicitly compares the speaker of Leaves of Grass with both the newspapers and the newspaper editors of his day. The advent of the penny press, combined with the high literacy rate, had meant for decades now that newspapers would be common, cheap, widely available, and intellectually accessible to almost any American. Nonetheless, editors depended on drawing attention to themselves in order to remain a step ahead of the pack. Whitman's on-the-job training in the industry introduced him to the concept of identifying at once with the product ("what is commonest and cheapest") and the producer ("spending for vast returns") - a perfect description of the peculiarly dual identity that epitomizes advertising characters. ${ }^{48}$

Thomas L. Brasher has speculated with good reason that the line "Backward I see in my own days where I sweated through fog with linguists and contenders" in "Song of Myself" was a memory of the poet's days at The Brooklyn Eagle and Kings County Democrat "when he contended with his contemporaries every day but Sunday and found it good." 49 The newspaper war often descended to the level of ad hominem slurs, which the Good Gray Poet-to-be concocted with surprising gusto. In an article he wrote for the New York Aurora, his previous employer Park Benjamin became a man "of impudence, conceit, and brazen assumption ... one of the most vain pragmatical nincompoops in creation." As editor of the Eagle, he described rival editor Henry Lees as "an English cockney, of fifty-sixth mental calibre, deficient of an original idea in his head." 50

Whitman's memoirs make clear that his mature poetic style, too, owed a debt to the intense competition he experienced as a writer during this period. In "A Backward Glance o'er Travel'd Roads," he explic- 
itly links an atmosphere of professional rivalry with the creation of the speaker of Leaves of Grass:

After continued personal ambition and effort, as a young fellow, to enter with the rest into competition for the usual rewards, business, political, literary, \&c.- to take part in the great mèlée. . . I found myself remaining possess'd, at the age of thirty-one to thirty-three, with a special desire and conviction . . . to articulate and faithfully express in literary or poetic form . . . my own physical, emotional, moral, intellectual, and æsthetic Personality, in the midst of, and tallying, the momentous spirit and facts of its immediate days, and of current America - and to exploit that Personality, identified with place and date, in a far more candid and comprehensive sense than any hitherto poem or book. (CPCP 657-658)

When he began publishing independently, entering Leaves of Grass into competition with other books for shelf-space, Whitman routinely figured himself both in his poetry and in the press as a heroic character vanquishing his moral and literary lessers. In one of his self-reviews he wrote typically, "And what is at once to become of the ranks of rhymesters, melancholy and swallow-tailed, and of all the confectioners and upholsterers of verse, if the tan-faced man here . . typifies indeed the natural and proper bard?"; the review constructs the publication of Leaves as a show-down with Tennyson's Maud, and Other Poems, in which, Whitman tells us, poetry takes on the "dandified" character of "a gentleman of the first degree." ${ }^{51}$

Whitman's later attacks on literary competition from abroad would continue to foreground the notion of poetry as abiding spirit born of competition. In "Song of the Exposition" (1871), commercial metaphors clash with classical allusions in a campaign to bring the muse stateside:

Come Muse migrate from Greece and Ionia,

Cross out please those immensely overpaid accounts,

That matter of Troy and Achilles' wrath, and Æneas', Odysseus' wanderings,

Placard "Removed" and "To Let" on the rocks of your snowy Parnassus ...

For know a better, fresher, busier sphere, a wide, untried domain awaits, demands you.

Away with old romance!

Away with novels, plots and plays of foreign courts,

Away with love-verses sugar'd in rhyme, the intrigues, amours of idlers, ...

To you ye reverent sane sisters

I raise a voice for far superber themes for poets and for art

$(\text { CPCP 342, 346-347) })^{52}$

European literature may well have been inadequate to American experience, as Whitman and others often claimed, but what was more 
demonstrably certain was that the availability of pirated European novels hobbled American authors until international copyright laws were passed in $1892 . .^{53}$

The figure of a poet much like Whitman and superior to other writers recurs constantly in Leaves, positing that there is no substitute for the contact we gain with him when we read. ${ }^{54}$ In the 1860 edition he claims extravagantly:

Of what I write from myself-As if that were not the resumé;

Of Histories-As if such, however complete, were not less complete than my poems;

As if the shreds, the records of nations, could possibly be as lasting as my poems;

As if here were not the amount of all nations, and of all the lives of heroes. ${ }^{55}$

The level of grandeur in the claim precludes any desire for objective support; the presentation of a being stupendous enough to make it is, in fact, its own message.

It would be ridiculous to pretend that advertising history could somehow "account for" Whitman; it would take a tin eye, as it were, to read Whitman merely as an eccentric literary hawker who bluffed his way into immortality. Beyond the often scandalously unpopular subject matter of his poems and the commercially suicidal absence of conventional pacing and organization, we should take into account that he himself had permanently mixed feelings on the subject of sales. In one of the darker portraits from the 1855 Leaves, he wrote, "This face is an epilepsy advertising and doing business ... The man falls struggling and foaming to the ground while he speculates well," though he later removed the phrase "advertising and doing business" (CPCP 126, 577). In his old age he called business both "an immense and noble attribute of man" and "what American humanity is most in danger of" (Reynolds 533, CPCP 1057). While Whitman was never free of financial worries, when he protests, "I do not say these things for a dollar" or (years later) pleads that we "Think not our chant, our show, merely for products gross or lucre," we are moved at least to give him the benefit of the doubt (CPCP 84, 350).

More important, though Whitman's persona shares some origins and features with advertising creations, the persona's relationship with us is never as monological as the conventional spokescharacter's. Leaves of Grass extends agency to the consumer in a way that would make little sense to conventional advertisers. This becomes particularly clear if we turn to what may be the poet's own richest commentary on the topic of re-inventing himself for mass production, the 1855 poem he would eventually call "A Song for Occupations." Positioned directly after the later-entitled "Song of Myself"- the longest and grandest poem in the book-and returning often to thoughts of the manufacture and public 
reception of text, it is in part the poet's meditation on the forthcoming entry of his own book into the American marketplace. "A Song for Occupations" opens with the speaker leaving his birth scene of "cold types and cylinder and wet paper," eager for the touch of his readers. ${ }^{56}$ Once incarnated in print, he immediately posits himself in competition with others who vie for our attention, be they teachers, proprietors, politicians, or employers. He grounds his own claim to us on his indifference to money and social standing:

The learned and virtuous and benevolent, and the usual terms;

A man like me, and never the usual terms.

Neither a servant nor a master am I,

I take no sooner a large price than a small price .... I will have my own whoever enjoys me,

I will be even with you, and you shall be even with me. (CPCP 89)

Spokescharacters commonly distract our attention from the industrial nature of the concerns they represent; indeed, that is largely why they exist. ButWhitman's speaker takes this disjunction further by exhorting us to disregard the producer altogether, cutting the ties between him and his creator, jealously refusing to represent at all:

I bring what you much need, yet always have,

I bring not money or amours or dress or eating . . . . but I bring as good;

And send no agent or medium .... and offer no representative of value-

but offer the value itself. (91)

What matters most is the mystical communion occasioned within us by the act of reading, coaxed into being by the material book but not to be contained within it: "All music is what awakens from you when you are reminded by the instruments" (94). Ideally, engaged and imaginative readers will look on Whitman's speaker not as the representative of a distant creator but as a present being whose words remind music out of us, spurring us to creative acts of our own.

Directing energy not out toward a product, as an ad would do, but toward our connection with the text itself, Whitman's teach-the-readerto-fish message evokes his own begrudging late praise of Emerson: "The best part of Emersonianism is, it breeds the giant that destroys itself. Who wants to be any man's mere follower? lurks behind every page." 57 It is a message that directly undercuts the standard function of advertising spokescharacters. The Jolly Green Giant would never teach us to destroy him (let alone to grow our own peas), but Whitman's speaker insists, "Not I, not any one else can travel that road for you, / You must travel it for yourself"; "He that by me spreads a wider breast than my 
own proves the width of my own, / He most honors my style who learns under it to destroy the teacher" (CPCP 82-83). The stakes could hardly have been higher. As he made clear in "Democratic Vistas," Whitman believed that active, creative, critical reading was nothing less than the training ground for fit self-government:

Books are to be call'd for, and supplied, on the assumption that the process of reading is not a half sleep, but, in highest sense, an exercise, a gymnast's struggle; that the reader is to do something for himself, must be on the alert, must himself or herself construct indeed the poem, argument, history, metaphysical essay - the text furnishing the hints, the clue, the start or frame-work. Not the book needs so much to be the complete thing, but the reader of the book does. That were to make a nation of supple and athletic minds, well-train'd, intuitive, used to depend on themselves, and not on a few coteries of writers. (CPCP 992-993) ${ }^{58}$

The mistake that Anne Gilchrist and other would-be lovers such as Susan Garnet Smith and Nellie O'Connor made was not exactly to "construct such an unauthorized \& imaginary ideal Figure, \& call it W.W." As I have said, Whitman himself had already done that. Where they went wrong was in equating this figure with the flesh-and-blood W.W. outside the book. It is to the point that none of Whitman's known romantic relationships were with readers of his poetry; his poems are anything but personal ads. As early as 1860 , in fact, he saw the need to advise readers that the speaker of Leaves was a fictional creation:

Are you the new person drawn toward me?

To begin with take warning, I am surely far different from what you suppose;

Do you suppose you will find in me your ideal?

Do you think it so easy to have me become your lover?

...

Do you suppose yourself advancing on real ground toward a real heroic man?

Have you no thought $\mathrm{O}$ dreamer that it may all be maya, illusion? (CPCP 277)

The difference between appearance and reality is, of course, a universal problem, but it is one with immediate significance to a poet who floats his first-person-singular pronoun so high. In "That Shadow My Likeness," first published in the same edition, Whitman openly explores the quandary of public identity:

That shadow my likeness that goes to and fro seeking a livelihood, chattering, chaffering,

How often I find myself standing and looking at it where it flits,

How often I question and doubt whether that is really me;

But among my lovers and caroling these songs,

O I never doubt whether that is really me. (CPCP 286)

On its surface, the poem seems to address the common distance people 
feel from the personalities they are required to project in public-in Whitman's case, the businessman "chaffering" (bargaining) with booksellers and newspaper editors. What complicates this reading is that there is no way to distinguish objectively the speaker of this poem from the complex "I" of the rest of Leaves. The speaker here may be airing his dissatisfaction with his author; imagine Mr. Clean having his say about working for Procter \& Gamble. The ambiguous first-person pronoun evinces perfectly what Lawson calls Whitman's “ambivalent embrace of the market's potentials for self-making." 59

Perhaps because he had not built in a more dramatically fictional persona, Whitman himself as he aged found it harder and harder to delineate where he ended and The Good Gray Poet began. Reynolds observes that after the war he began referring to himself in the third person even in his notebooks. ${ }^{60}$ The poet's increasing investment in his alter-ego as strokes and other maladies eroded his accustomed good health links him with the American consumers of his time, whose desire for the more human scale of the pre-industrial past led them to embrace a growing influx of advertising spokescharacters. In much the same way that spokescharacters softened American consumers' alienation from the means of production, the "Good Gray Poet" image softened Whitman's sadness over his loss of health. The confusion of his later years testifies to the efficacy of his own extended advertising campaign.

Seeing Whitman's self-fictionalization as such should have a salutary (to borrow the snake-oil salesmen's word) influence on our perception of his work. On one hand, it should encourage us to give him his due as an innovative promotional writer. Though any claim that Whitman had much influence over the course of advertising history would be groundless, his poetry does evince an independent discovery that generally paralleled advertisers' in motivation and method. More important, recognizing the element of "internal self-promotion" in Leaves may help readers unify two frequently opposed Walt Whitmans: the mystic and the opportunistic press-monger. Whitman's iconoclastic mix of poetry and advertising epitomizes his struggle to reconcile his visions of proletarian utopia and industrial capitalism. Though he was only faintly aware of the nascent strategy of endowing the mass-produced artifact with a living soul, it was by employing it that he so effectively urged his readers to read critically and athletically, resisting the homogenizing influence of the marketplace he begrudgingly adored.

\section{The University of Mary Washington}




\section{NOTES}

1 Oscar Wilde, The Picture of Dorian Gray, in Complete Works of OscarWilde (New York: Harper \& Rowe, 1989), 55.

2 David S. Reynolds, Walt Whitman's America:A Cultural Biography (NewYork: Random House, 1996), 492.

3 Walt Whitman, Complete Poetry and Collected Prose, ed. Justin Kaplan (New York: Library of America, 1982), 50. Hereafter CPCP.

4 Thomas B. Harned, ed., The Letters of Anne Gilchrist and Walt Whitman (New York: Doubleday, Page \& Co., 1918), 47-48.

5 M. Jimmie Killingsworth, "Whitman's Physical Eloquence," in Walt Whitman: The Centennial Essays, ed. Ed Folsom (Iowa City: University of Iowa Press, 1994), 69.

6 John T. Irwin, American Hieroglyphics: The Symbol of the Egyptian Hieroglyphics in the American Renaissance (Baltimore: Johns Hopkins University Press, 1980), 99.

7 Andrew Lawson, “'Spending for Vast Returns': Sex, Class, and Commerce in the First Leaves of Grass," American Literature 75 (2003), 335-365; Terry Mulcaire, "Publishing Intimacy in Leaves of Grass," ELH 60 (1993), 471-501.

8 Daniel J. Boorstin, The Americans: The Democratic Experience (New York: Vintage Books, 1974), 122-124. In reply, Ward "shrewdly advised that it was not wise to select a wife by mail, but added that 'after you get the wife and you find that she needs some wearing apparel or household goods, we feel sure we could serve both you and her to good advantage."”

9 Mulcaire, 490.

10 Among recent commentators on Whitman and advertising, Sean Francis finds Whitman's desire to distance himself from advertising doggerel to have been an important factor in his rejection of fixed rhyme and meter ("'Outbidding at the Start the Old Cautious Hucksters': Promotional Discourse and Whitman's 'Free' Verse," NineteenthCentury Literature 57 [2002], 381-406). In "Prisoner, Fancy-Man, Rowdy, Lawyer, Physician, Priest:Whitman's Brags,"William Logan finds continuities between Whitman's self-promotion and the colorful tradition of American bragging, while Heather Morton's "Democracy, Self Reviews, and the 1855 Leaves of Grass" investigates how the poet's self-promotion served not only to boost sales but also to teach the public how to read (both in The Virginia Quarterly Review 81 [Spring 2005], 19-33 and 229-243). See also Lawson and Mulcaire. On the related issue of Whitman's support of literary property rights, see Martin T. Buinicki, "Walt Whitman and the Question of Copyright," American Literary History 15 (2003), 248-275. For a discussion of Whitman's place in the context of nineteenth-century book promotion in particular, see my own "Peddling Whitman: Leaves of Grass and the American Marketplace," Mickle Street Review 14 (Summer 2001), http://www.micklestreet.rutgers.edu/archives/Issue \%2014/essays/earnhart_files/earnhart. htm.

11 James Playsted Wood, The Story of Advertising (New York: The Ronald Press Co., 1958), 23-24; Frank Presbrey, The History and Development of Advertising (Garden City, NY: Doubleday, Doran, \& Co., 1929), 19-22.

12 Jackson Lears, Fables of Abundance: A Cultural History of Advertising in America (New York: Basic Books, 1994), 384.

13 Lears, 143, 385. 
14 Roland Marchand, Creating the Corporate Soul: The Rise of Public Relations and Corporate Imagery in American Big Business (Berkeley: University of California Press, 1998), 26.

15 "When he saw the logo for the Walt Whitman cigar, he laughed, 'That is fame!,", Reynolds relates, adding that Whitman's name would later be appropriated to dignify even a New York shopping mall.

16 Stephen Fox, The Mirror Makers: A History of American Advertising and its Creators (New York: Morrow, 1984), 18. Like the ghost-written “Ann Landers” of today's papers, the alter-ego Pinkham created not only outshone but outlived her. For long after her widely-publicized death in 1883, her heirs (capitalizing on the same confusion that had brought Whitman's suitor Anne Gilchrist to America) eerily continued to urge customers with "female complaints" to seek the advice of "Mrs. Pinkham in her laboratory at Lynn, Mass.” The letters continued to pour in (Wood, 327-330).

17 Fox, 24.

18 Marchand, 27.

19 Quoted in Lears, 293.

20 Quoted in Lears, 291.

21 For an extended discussion of this portrait and its relation to Whitman's "conflating two bodies, his own and that of his book," see Ed Folsom's "Appearing in Print: Illustrations of the Self in Leaves of Grass," in Ezra Greenspan, ed., The Cambridge Companion to Walt Whitman (New York: Cambridge University Press, 1995), 135-165.

22 Kenneth Price, ed., Walt Whitman: The Contemporary Reviews (New York: Cambridge University Press, 1996), 22.

23 Milton Hindus, ed., Walt Whitman: The Critical Heritage (New York: Barnes and Noble, 1971), 116.

24 Nathan Resnick has argued that Whitman did, in fact, ghostwrite the homage (Walt Whitman and the Authorship of "The Good Gray Poet" [Brooklyn: Long Island University Press, 1948]), and even W. Gordon Milne's skeptical retort ("William Douglas O'Connor and the Authorship of The Good Gray Poet," American Literature 25 [March 1953], 3142) concedes that the poet probably contributed to it.

25 Mulcaire, 472-477.

26 Gay Wilson Allen, The Solitary Singer: A Critical Biography of Walt Whitman (New York: Macmillan, 1955), 131. Emphasis added.

27 Karen Halttunen, Confidence Men and Painted Women: A Study of Middle-Class Culture in America, 1830-1870 (New Haven: Yale University Press, 1982), 12-21.

28 I Sit and Look Out: Editorials from the Brooklyn Daily Times by Walt Whitman, ed. Emory Holloway and Vernolian Schwarz (New York: Columbia University Press, 1932), 125. Hereafter I Sit.

29 Betsy Erkkila, Whitman the Political Poet (NewYork: Oxford University Press, 1989), 38.

30 Emory Holloway, ed., The Uncollected Poetry and Prose of Walt Whitman. 2 vols. (New York: Peter Smith, 1932), 20. Hereafter UPP. 
31 Though sometimes used to disparage gossipy or biased writing, "personal journalism" often referred simply to the melding of the editor's personality with the newspaper. One 1887 eulogy, for instance, admiringly described Horace Greeley as "the last representative of that personal journalism which made editor and paper one thing. The plain country reader always religiously believed that Horace Greeley wrote everything that was printed in the Tribune, unless it was the signed letter of some correspondent" (Joel Benton, "Reminiscences of Horace Greeley," The Cosmopolitan 3, no. 5 [1887], 311). There seems to be no connection between this term and Whitman's "personalism," which he uses more or less interchangeably with "individuality."

32 William E. Huntzicker, The Popular Press, 1833-1865 (Westport, CT: Greenwood, 1999), 169.

33 Richard Ohmann, Selling Culture: Magazines, Markets, and Class at the Turn of the Century (New York: Verso, 1996), 187. It seems ironic, as Ezra Greenspan has pointed out, that editors "cultivate[d] a bond of familiarity between reader, editor, and journal ... at the moment when the incipient age of mass circulation was actually putting distance between them," but the familiar pose was partly an anxious reaction to that very distance (Ezra Greenspan, Walt Whitman and the American Reader [NewYork: Cambridge University Press, 1990], 108).

34 The newspaper wars are closely echoed by our modern-day proliferation of news sources via cable and Internet, and by the concomitant emphasis on charismatic figureheads. As Richard A. Posner notes, "the salaries paid news anchors have soared: the more competition there is for an audience, the more valuable is a celebrity newscaster" ("Bad News." The Nerw York Times [July 31, 2005], 3).

35 Andie Tucher, Froth E Scum:Truth, Beauty, Goodness, and the Ax Murder in America's First Mass Medium (Chapel Hill: University of North Carolina Press, 1994), 138.

36 Frank Luther Mott, American fournalism (New York: Macmillan, 1950), 229, 232, 235.

37 Greenspan, Whitman and the American Reader, 48-55.

38 See also Greenspan, Whitman and the American Reader, 48-55.

39 In the 1855 preface, for instance, "Come to us on equal terms, Only then can you understand us, We are no better than you, What we enclose you enclose, What we enjoy you may enjoy" (CPCP 14); or in what he was to call "Song of Myself": "This hour I tell things in confidence, / I might not tell everybody but I will tell you" (45). See also Greenspan, 79 .

40 Hazel Dicken-Garcia, Fournalistic Standards in Nineteenth-Century America (Madison: University of Wisconsin Press, 1989), 295, n3.

41 Thomas L. Brasher, Whitman as Editor of the Brooklyn Daily Eagle (Detroit: Wayne State University Press, 1970), 46-47.

42 Charles Goodrum and Helen Dalrymple, Advertising in America:The First 200 Years (New York: Harry N. Abrams, Inc., 1990), 18-19.

43 Lears, 289. See also James B. Twitchell, Adcult USA: The Triumph of Advertising in American Culture (New York: Columbia University Press, 1996), 115-116.

44 Despite the insidious implications of this development, one positive side-effect of branding was that it did away with manufacturers' anonymity. To generate consumer 
goodwill toward their no-longer-unknown names, it became worthwhile for manufacturers to enforce quality control.

45 Allen, 32, 47; Tucher, 7.

46 Presbrey, 199-200.

47 Wood, 161-164.

48 A writer on contemporary spokescharacters relates that "sober-suited corporate executives spend their days pondering such ontological questions as: Does the Pillsbury Doughboy actually make the cookies, and if so, are they made from parts of himself? (The answer, if you're curious, is that while the Doughboy is clearly related to the product in an 'ownership' way, in that he refers to the product as 'my cookies,' it is never explained exactly how he creates them. 'We don't want people to really think about that part,' says [brand development director Dennis] Ready)." Ruth Shalit, "The Inner Doughboy: How an army of admen battle to define and protect the true nature of the Jolly Green Giant, the Pillsbury Doughboy and other advertising spokescharacters," Slate 23 (March 2000), $<$ http://archive.salon.com/media/col/shal/2000/03/23/doughboy/index.html>, 3.

49 Brasher, 37.

50 Allen, 46; Brasher, 34.

51 Walt Whitman:The Contemporary Reviews, ed. Kenneth Price (NewYork: Cambridge University Press, 1996), 25, 24.

52 It is interesting to note that the anaphora of this passage is itself an image of its me-against-the-world message. The genres Whitman is doing away with are presented in a monotonous set of lines; each is made equal to the others by the introduction "away with," and Whitman's own voice is offered as a cure. An undated nineteenth-century ad for Brandreth's Pills exploits the form in a similar way:

Whether it be asthma or consumption,

Whether it be rheumatism or pleurisy,

Whether it be typhus fever and ague, or bilious fever;

... Brandreth's Pills will surely do more than all the medicines of the drug stores for your restoration to health. (Quoted in J. R. Dolan, The Yankee Peddlers of Early America [New York: Bramhall, 1964], 199.)

Just as the Brandreth's ad pits its client against illness and "all the medicines of the drug stores,"Whitman pits himself against his rivals in the literary marketplace. As this similarity indicates, Sean Francis's interesting contention that Whitman abandoned rhyme because its power had been "neutered" by promotional poetry is compromised by the fact that Whitman's alternative formal strategies often echoed those of newspaper ads (Francis, 391).

53 For more on Whitman's attitudes toward competition and copyright, see Reynolds, 81-82, and Buinicki.

54 "The Real War Will Never Get in the Books" might be more accurately titled "The Real War Will Never Get in Any Books but Mine."

55 Leaves of Grass (Boston: Thayer and Eldridge, 1860), 411. 
56 Though Reynolds has defended the "mechanical" feel of these descriptions as an "effort to present 'natural forms' free of artifice and sensationalism," we might also surmise that Whitman had a literal machine - the cylinder press - in mind as he wrote (Reynolds 212).

57 Quoted in Justin Kaplan, Walt Whitman: A Life (New York: Simon and Schuster, 1980), 210.

58 For further discussion of Whitman's vision of the importance of reading in America, see Greenspan, Chapter 6.

59 Lawson, 343.

60 Reynolds adds, "It's not enough to say, as some have, that Whitman became his own 'press agent.' True, he was that from the start, but after the war his 'agent' (himself) became intertwined with his 'press' (the image he and his friends were pushing)" (489). 